\title{
Taxing the cloud: introducing a new taxation system on data collection?
}

\author{
Primavera De Filippi \\ (Panthéon-Assas), France \\ Published on 01 May 2013 | DOI: 10.14763/2013.2.124
}

Research and Studies Center of Administrative Science (CERSA/CNRS), Université Paris /I

\begin{abstract}
Cloud computing services are increasingly hosted on international servers and distributed amongst multiple data centres. Given their global scope, it is often easier for large multinational corporations to effectively circumvent old taxation schemes designed around the concept of territorial jurisdiction and geographical settings. In view of obtaining tax revenues from these online operators whose business is partially carried out in France, the French government recently issued a report emphasising the need for new taxation rules that would better comply with the way value is generated in the digital economy: at the international level, it is suggested that taxation should be calculated according to the place of interaction with endusers; at the national level, the report suggests to introduce a transitory tax on data collection in order to promote innovation and encourage good online practices.
\end{abstract}

Keywords: Taxing, Cloud services, Apple, Google, Amazon, Facebook, Twitter, France, Cloud, Cloud computing, Taxation, Fiscality, Data protection, Data collection

\section{Article information}

Received: 25 Mar 2013 Reviewed: 03 Apr 2013 Published: 01 May 2013

Licence: Creative Commons Attribution 3.0 Germany

Competing interests: The author has declared that no competing interests exist that have influenced

the text.

URL:

http://policyreview.info/articles/analysis/taxing-cloud-introducing-new-taxation-system-data-collectio $\mathrm{n}$

Citation: De Filippi, P. (2013). Taxing the cloud: introducing a new taxation system on data collection?. Internet Policy Review, 2(2). https://doi.org/10.14763/2013.2.124

Information and communication technologies (ICT) are a growing source of innovation and wealth which potentially affects every sector of the economy (online and offline). Although it is important to account for the specificities of the digital environment, tax regulations should apply equally to online and offline operators. Yet, fiscal revenues derived from the commercial activities of many internet giants - such as Google, Amazon, Apple or Facebook - do not seem to follow the same trend.

Indeed, according to the French Telecom Federation, more than 5 billion euros are collected every year by these companies through their interactions with French citizens, but only a really 
small fraction thereof is actually accounted for when establishing the amount of taxes paid to the French government. For instance, Google alone is suspected to have achieved in 2011 a turnover between 1.25 and 1.4 billion euros (most of which is derived from advertising activities on the internet) but only paid a little bit over 5 million euros as corporate income tax to the French government. 1

">http://www.fftelecoms.org/sites/fftelecoms.org/files/contenus_lies/brochure_ott_4_pages. pdf

Digital taxation has become an important concern for many governments, in Europe and beyond: countries such as Germany, the United Kingdom and the United States have been trying to tackle the issues of tax avoidance and profit shifting for many years, both at the national and international levels. More recently, the issue has been specifically addressed by the French government, which sets out to start a "war against tax piracy" in the cyberspace through the introduction of a new tax - which, if implemented, would effectively put France at the frontline in terms of digital taxation regulations.

In this regards, a series of verification procedures have been undertaken against large multinational groups suspected to avoid compliance with French tax regulation by billing most of their customers from abroad, so as to evaluate the amount of money owed $\square \square$ to the French state. In addition to Microsoft - which has been requested to pay 52.5 million euro for tax evasion - the main targets are Google, Amazon, Facebook and Apple (the so-called "GAFA gang") suspected to pay only a very limited share of corporate income taxes.

In June 2011, the National tax inspection authority and French customs conducted a raid on the headquarters of Google France. After having examined several emails, invoices, and other contracts with a view to determine the amount of value-added tax (VAT) and corporate income tax which had not been paid by the company between 2008 and 2010, it appears that the U.S. company might have to pay damages for more than 100 million euros. Few months later, it is the turn of Amazon to be investigated. After thorough analysis, the Tax inspection authority asked the U.S. company to pay 198 million euros of tax arrears, interests and penalties related to the false reporting of foreign sales in France. Finally, the French tax inspection authority conducted a search in the Paris headquarters of Facebook, in order to double-check the veridicity of the company's tax returns declaration. Like the other two companies, Facebook is suspected to divert most of its revenues through Ireland in order to benefit from laxer tax regulations.

This practice, generally referred to as the practice of tax avoidance - as opposed to tax evasion, consists in using the taxation system to one's advantage, so as to legitimately reduce the amount of due taxes without infringing the law. This practice has become widespread on the internet, due to the ability for large online operators to circumvent an aging taxation scheme that is designed around the concept of territorial jurisdiction and geographical settings. Tax avoidance is in fact much easier to achieve in the context of cloud computing services, hosted on international servers and distributed amongst multiple data centres which are not necessarily located in the country where taxes are due.

Thus, in view of obtaining proper tax revenues from online services provided by international corporations whose business is partially carried out in France, the French government has commissioned a study (analysed in detail below) to find out how to effectively deal with internet giants that are suspected to constantly experiment with new tax optimisation schemes with the goal to reduce tax contributions to a minimum. 


\section{FRENCH REPORTS ON NEW TAXATION RULES FOR THE DIGITAL ECONOMY}

After a first report filed on June 27, 2012 by French Senator Philippe Marini (Chairman of the Finance Committee) presenting the roadmap for a neutral and equitable taxation scheme for the digital world, the French government decided to address the question of "digital taxation" (fiscalité numérique) more in depth. In an interview with Le Monde, the French Minister for the digital economy, Fleur Pellerin, explains that "as Europe is increasingly turning into a tax haven for large multinational corporations", the French government intends "to restore a balance between online and offline operators". Thus, following Marini's report, the French Ministries of Finance and Economic Regeneration commissioned a study aimed at fighting tax piracy in the cyberspace. The findings of this study have recently been presented in the form of a comprehensive (and slightly controversial) report - published on January 22, 2013 - which emphasises the need for new taxation rules at the national and international level.2

Indeed, the advent of internet and digital technologies challenged the traditional approach to corporate taxation - whose rules have rapidly become obsolete with the advent of cyberspace. Many online operators rely on innovative business models with large productivity gains that do not, however, generate any revenue for the states they operate in. According to the authors of the report, this is due to three important factors: Firstly, the rapid and constant evolution of online practices and activities makes it difficult to identify specific points of stability on which to levy a tax. Secondly, these online practices systematically dissociate the place of establishment (of the company providing the service) with the place of consumption (by the user of that service). The wealth generated by these companies is, therefore, increasingly difficult to locate, and, consequently, ever more difficult to tax. Thirdly, given that most of the large online operators are either vertically or horizontally integrated, they can split their businesses into several companies so as to separate data collection activities from the activities that actually generate profits. Thus, it becomes easy for these companies to transfer their profits into offshore tax havens, where they can benefit from divergent tax regulation. Such is the case of Google, which in 2011, managed to save up to 2 billion US dollars in corporate income taxes by shifting 9.8 billion US dollars in revenues into a Bermuda shell company.

The report proposes to reform taxation systems to better comply with the way value is generated in the digital economy: at the international level, it is suggested that taxation should be calculated according to the place of interaction with end-users; at the national level, the authors suggest to introduce a transitory tax on data collection in order to promote innovation and encourage good online practices.

\section{TAXATION ACCORDING TO THE PLACE OF INTERACTION}

International tax laws require corporate profits to be taxed according to the law of the country in which the corporation's headquarters are located - which is often the country with the lowest taxation rate. Sometimes, other countries can nonetheless levy corporate taxes when the company enjoys a "permanent establishment" in that country - a concept defined by the OECD Model Tax Convention, which constitutes the basis of corporate taxation in most EU member 
states.

Yet, given that the concept of "permanent establishment" did not keep up with recent developments of the digital economy, its redefinition was suggested in order to better comply with the specificities of a "data-driven digital economy". Based on the new role of users as cocreators of value in the supply chain, the notion of "permanent establishment" should not only account for the physical location of the servers on which the services are hosted, but also for the place of interaction with end-users 3 - which is where the process of value creation actually takes place.

The problem is, of course, that international taxation schemes are based on international tax treaties and mutual agreements amongst countries. The implementation of such a proposition will thus necessarily require a long period of negotiations both at European and international level.

\section{TRANSITORY TAX BASED ON DATA COLLECTION}

In the meantime, the authors of the report suggest to intervene at the national level, in order to better account for the role of data in value creation by introducing a "transitory internet tax" based on the collection and processing of user data.

Indeed, all internet intermediaries (and cloud computing operators in particular) have the ability to collect a large variety of user data - be it data provided voluntarily by users, data derived from the systematic monitoring of user activity, or data involuntarily left behind while surfing the internet. Such data can be exploited in many ways: to provide target advertising, to make purchase recommendations, to better customise a product, to increase customer loyalty and trust, or to apply price discrimination - all activities that might lead (directly or indirectly) to greater customer satisfaction and higher profitability.

The authors claim that data - and especially personal data - "are the goldmine of the digital economy", and should therefore be regarded as one of the main drivers of economic growth. Just like goods, data can be stored, aggregated and reused at a later time, so as to provide new value in the long term.

\section{INTERNET USERS AS CHEAP LABOUR}

More and more, on the internet, as users become an integral part of online business operations, the line between consumption and production begins to blur. Large social networks, such as Facebook, Youtube or Google+ strongly benefit from "the free and voluntary contribution of internet users" - which includes both personal data and user-generated-content. Yet, given that they are not paid for, user contributions (described by the authors as "free labour", as opposed to "crowdsourcing" 4 ) constitutes a strategic source of revenue for many cloud operators and online intermediaries. Indeed, by leveraging on data produced by user activity, online operators can provide many of their services for free, while nonetheless making significant profits through the commercial exploitation of such data. Besides, user contributions can easily be capitalised upon to either boost advertising revenue or to increase the user-base for other complementary (paid) services. Traditional taxation schemes, however, generally fail to take these practices into account. 
Hence the proposition to introduce "a tax on the collection, processing and commercial exploitation of user data" - whose rate would be determined according to the number of users and the intensity of data collection. While any company that "regularly and systematically" collects user data could potentially be affected by such a tax, it would, however, only apply "above a specific threshold of users" who are physically located in France. According to the report, the volume of data collected from French users would be determined on the basis of a self-declaration by every foreign company, but would always remain subject to inspection by the tax authorities. Failure to comply with such an obligation would result in the tax rate being calculated according the total flow of data transferred outside of France.

The advantage of using "data" as a basis for taxation is that it constitutes a "neutral tax basis" which applies to most of the activities in the online economy. Yet, establishing a tax over data collection per se would not be constitutionally valid to the extent that it would infringe the

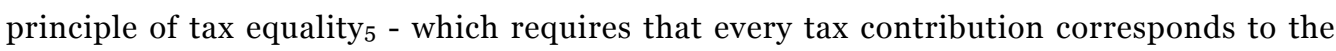
contributor's ability to pay. However, since every company does not produce the same value with the data it collects, determining the profits that potentially could derive from the exploitation of such data can be a very difficult task.

Hence, rather than as a means to increase state revenues, the idea is to design the tax an "incentive for virtuous behaviour".

There are, in fact, many cases in which taxation is not proportionate to the actual profits generated by the company. This is the case of all the taxes whose main purpose is to encourage contributors to behave in a way that is compliant with the general interests of society - such as, for instance, the French taxes on polluting activities (TGAP) or the "carbon tax" aimed at lowering the impact of carbon dioxide emission on the environment.6

Drawing from these examples, the idea suggested by the two authors is to use the proposed "internet tax" to promote business transparency and good practices, encouraging online operators to innovate without impinging upon users' rights.

The authors, furthermore, propose that the new tax regulation would only levy a tax insofar as the company does not comply with the specific requirements of the law in terms of user privacy and empowerment and, its rate would ultimately depend on the company's behaviour and online practices (as assessed by independent auditors). It would be adjusted to favour companies that comply with relevant data protection laws, respect individual liberties, and properly disclose their data - either to the individual concerned (smart disclosure 7 ) or to society as a whole (through open data8 or open APIs9) - in a format allowing for easy access and reuse. Conversely, companies collecting or exploiting personal data without providing proper notification to their user-base, or companies providing insufficient access to that data might be taxed more heavily.

\section{IMPACT AND INTERNATIONAL CONSIDERATIONS}

Many cloud operators - such as Google, Facebook, Apple, Amazon and Twitter - would obviously be affected by the proposed new taxation scheme. Yet, they are not the only ones. Traditional businesses (such as online banking, web-mail and e-commerce platforms, or any website that collects a large number of customer information) could also be affected by this new tax to the extent that - provided that they operate under French law - they will have to pay for the 
collection or processing of French user data.

The authors of the report acknowledge that an in-depth impact study is needed to ensure that the tax only applies to the type of companies it was meant for. Until then, it was suggested that, for the sake of simplicity, the tax would initially apply - on an experimental basis - only to the providers of mobile applications (such as Apple Store, Google Play Store, Blackberry's App World, or Amazon's Kindle Fire Apps) whose identification is easiest. These operators would thus become liable to the French state to pay for the collection of user data - with a tax rate calculated on the amount of data collected and the manner in which it has been collected.

Thus far, the report has spurred great interest and debate. While the general principle of a transitory taxation scheme for the digital economy seems relatively sound, linking this tax to the collection of user data has nonetheless generated considerable controversy both in France and abroad (such as in Germany, Spain, Italy, the U.K. and the U.S.)

The French government still has to take a position concerning the new internet tax - which might raise a large number of challenges as regards its legitimacy and practical implementation both in the national and international framework. Indeed, after having described the report as "intellectually outstanding", Mr. Retailleau (Senator and Rapporteur of the report on behalf of the Economic and Finance Committee) expressed his concerns that the "practical and operational implementation" of these recommendations seems to be "very delicate". In this regards, the Conseil National du Numérique (CNN) - a digital affairs advisory council to the French National Assembly - has recently been requested to assess the viability and the potential consequences of such a new taxation scheme, which could potentially be introduced in the 2014 Financial Bill.

The implementation of this new tax would put France at the forefront of international policy making, by establishing a new taxation system for the digital economy. This system would not only establish more fiscal accountability for processors of personal data, it also might allow France to impose its own data protection standards on a variety of multinational online operators.

At the international level, international negotiations to adapt tax regulations to the digital economy are to be expected at the next G20 Finance summit on February 14-15th, 2014 - in the framework of the OECD's action plan against tax avoidance.

\section{FOOTNOTES}

1. Greenwich Consulting Study for the French French Telecom Federation. April 2013. 2. The study was composed of two experts - Pierre Collin (State Councilor and specialist tax lawyer) and Nicolas Colin (Inspector of Finances) - whose mission was to propose a series of changes to national and international tax regulations so as to better account for the value created by online firms.

3. A similar position has recently been taken by the French data protection authority (Commission nationale de l'informatique et des libertés) as regards the protection of personal data, which - it is claimed - should not be regulated exclusively according to the law of the country where the servers are located.

4. Wikipedia defines crowdsourcing as the practice of obtaining needed services, ideas, or content by soliciting contributions from a large group of people, and especially from an online community, rather than from traditional employees or suppliers. A narrower definition is 
provided by web strategist Henk van Ess, according to whom crowdsourcing is "channeling an expert's desire to solve a problem and then freely share the answer with everyone" - a definition which emphasises the ethical need to return the resulting contributions to the community.

5. In French law, the principle of tax equality (principe d'égalité devant l'impôt) is derived from Article 1 ("Men are born and remain free and equal in rights") and Article 13 ("A general tax [...] must be equally distributed among all citizens, in proportion to their ability to pay") of the Déclaration des Droits des Hommes et des Citoyens, as well as Article 1 of the 1958 Constitution which states that France guarantees equality before the law for all citizens without distinction of origin, race or religion.

6. A number of countries have implemented carbon taxes or energy taxes that are related to carbon content. Most environmentally related taxes with implications for greenhouse gas emissions in OECD countries are levied on energy products and motor vehicles, rather than on $\mathrm{CO} 2$ emissions directly.

7. Smart disclosure is when a private company or government agency provides a person with periodic access to his or her own data in open formats that enable them to easily put the data to use.

8. Open data is the idea that certain data should be freely available to everyone to use and republish as they wish, without restrictions from copyright, patents or other mechanisms of control.

9.: The term Open API has been in use based on recent trends in social media and Web 2.o. It is currently a heavily sought after solution to interconnect websites in a more fluid user-friendly manner. Open API also applies to collaborative services environments where managed service providers can also outsource specific services to other providers via systems integration 